\title{
a community called...
}

The Copyright law of the United States (title 17, United States code) governs the making of photocopies or other reproductions of copyrighted material. Under certain conditions specified in the law, libraries and archives are authorized to furnish a photocopy or other reproduction. One of these specific conditions is that the photocopy of reproduction is not to be "used for any purpose other than private study, scholarship, or tesearch." If a user makes a request for, or later uses, a photocopy or reproduction for purposes in excess of "fair use," that user may be liable for copyright infringement. This institution reserves the right to refuse to accept a copying order if, in its judgment, fulfillment of the order would involve violation of copyright law.

By using this material, you are consenting to abide by this copyright policy. Any duplication, reproduction, or modification of this material without express written consent from Asbury Theological Seminary and/or the original publisher is prohibited.

Asbury Theological Seminary 2011

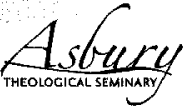




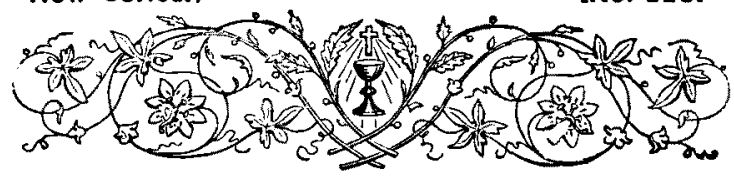

\section{TEMPERANCE AND PROHIBITION.*}

Reaffirming all our former deliverances on total abstinence and the prohibition of the liquor traffic, we submit for your adoption the following sections:

\section{I.-Progress and Duty.}

We have ample reason for congratulation that the temperance reform is engaging public attention as never before. While some minds are yet torpid, not apprehending the vital issues, and while, to some intense reformers, such loitering in the march of reform seems unpardonable, nevertheless a growing multitude of redoutable men and women are learning both $t$, wait and to hasten with Providence. In this great moral ad-

* Adopted by the General Conference of the Methodist Episcopal Church, May, 1888. 
vance, we recognize the duty of the Methodist Episcopal Church, with all other Christian bodies, to march at the head of the column, to inspire and direct the movement.

\section{II.-Temperance Organizations.}

In response to the memorial address to this body by the Woman's Christian Temperances Union, we gladly recognize with high appreciation their great work, "preventive, clucational, evangelistic, social, and legal," and the extension of its sphere, through its eminent representatives abroad, in the great foreign mission countries. We also tender fraternal greetings and a hearty God-speed to the National Temperance Society, and all other organizations engaged in advancing this reform, especially to all who labor upon a gospel temperance basis. We welcome our adopted fellow-citizens to these expanding ranks. Wo urge a spirit of kindly conciliation and cordial co-operation among all temperance workers. We recommend that the Temperance Committees appointed by the Quarterly ConferNo. 220 . 


\section{Temperance and Prohibition.}

ences in all our charges, and the Annual Conference Temperance Societies, seek to enlist our people more fully in this great movement against the drink customs and the drink traffic which disgrace our civilization.

\section{III.-Total Abstinevce.}

We renew our time-honored testimony in favor of total abstinence from all alcoholic liquors. The best modern science has irrefragably demonstrated that there is no legitimate place for alcohol, not even in the form of the milder liquors, and in however moderate quantities, in a healthy living organism. This testimony of science has been independently confirmed, by the impartial demonstrations of life-insurance experts, critically seeking sure bases on which to conduct great financial interests. Total abstinence is now fully vindicated, as something more than a "dietetic whim," or a fanatical craze; and we can accept of nothing less than this, as security for personal safety, and as the basal principle of the temperance reform.

No. 220 . 


\section{Temperance and Prohibition.}

IV.-Scientific Temperance Instruction.

We hail with joy the enactment of laws providing for scientific temperance instruction in the public schools of thirty-four states and territories, under which six and a half million of children and youth are being taught the evils of alcoholic beverages. We urge that those laws be strengthened, whenever necessary, by suitable self-enforcing penalties. We also call for the exclusion from the schools of those professedly temperance but fatally misleading text-books, which directly or impliedly encourage the moderate use of the milder intoxicants. We are glad to learn that many of the publishers of such books have undertaken a revision, and are now bringing them to the scientific standard of total abstinence. I et the text-books which are to shape our children's lives be closely scrutinized.

V.-Raising of Grapes, Hops, etc.

We approve the action of the Lay Electoral Conference of California, condemning the raising and selling of grapes for the manu. No. 220 . 
facture of fermented wine, and we thiuk the time has come for a broader ntterance npon this subject. We warn ou" members against raising and selling, not only grapes, but also other fruits, hops, and grain, for the manufacture of alcoholic liquors, as inconsistent with the Christian profession, benumbing to the conscience and hurtful to the cause of temperance and true piety. These practices bring the Church into complicity with the great liquor nuisance, paralyze our efforts and afford comfort to the greatest enemy of modern Christianity.

VI.-Our Retation to the Liquor T'Raffic.

We reiterate the language of the Episcopal Aldress to this boly:

"The liquor traftic is so pernicious in all its bearings, so inimical to the interests of honest trade, so repugnant to the moral sense, so injurious to the peace and order of society, so hurtful to the home, to the Church, and to the body politic, and so utterly antagonistic to all that is precious in life, that the only

No. 220. 
proper attitude toward it for Christians is that of relentless hostility. It can never be legalized without sin." And we furthermore emphatically declare that men engaged in the manufacture and sale of alcoholic beverages onght not to receive commercial patronage or the suffrages of Christian people for any political office, or any position of influence on educational boards.

\section{ViI.-Practical Political Action.}

One of the dark reproaches of our times is that the saloon has been allowed to become a political gambler, and to do brokerage business with the ballot-box as a part of its stock in trade. Saloons and corrupt politicians constitute an equation, both members of which have a ballot-box value, and are easily transferred. We urge it as an imperative duty of Christian men to attend the primaries, to wrest the sovereignty of the caucus from the grip of the saloon, to purify and elevate the caucus by their presence, and make it a promoter of morals and good order. Beginning No. 220 . 
with the caucus, let us work upward through all the departments of legitimate civil action, until our entire citizensnip is emancipated from this bondage. We must supplant the five or six thousand legislators and the tens of thousands of municipal officers, who have long stood as the body-guard of the saloon in its ravages upon the home.

\section{VIII.-Enforcement of Liquor Laws.}

The habitual non-enforcement of law is an impediment in the way of all true, moral, and social reforms. We rejoice in the awakening sentiments among American people in favor of a more rigorous enforcement of civil statutes. We are grateful to those eminent civilians in Chicago, New York city, and elsewhere, who, in very conspicuous instances, within a few years, have so effectively vindicated the sanctions of law and government. We hold in profound veneration the heroic example of our martyred brother, the Rev. Geurge C. Haddock, struck down by an assassin's bullet while protecting society against No. 220. 
saloon lawlessness; and, believing that one of the most important methods for promoting temperance is to enforce law, we call upon our people every-where, without distinction of party, to lend their efforts for the faithful administration of the restrictive, suppressive, and probibitory features of existing liquor laws.

IX.-The Legal Status of Liquor Traffic.

We rejoice in the decision of the Supreme Court, at Washington, D. C., in December last, fully vindicating the most radical legislation against the liquor traffic in our most advanced prohibitory States. Fully realizing the difficulty of protecting society, by merely moral forces, against evils sanctioned under the broad seal of the commonwealth, we call upon our people to assist in securing in all the States, as rapidly as possible, such legislation that liquor dealers "shall no longer have a law-book as a pillow, nor quiet their consciences with the opiate of a court license." The absolute suppression of the saloon is our objective point. Some States anil some localNo. 220 . 
ities cannot advance as rapidly as others. We will of ten find the means for securing our objects dependent upon conditions we cannot easily, or at once control, and the judgment and conscience of every citizen must be left free to determine for himself what course he will pursue. While, howerer, we concentrate every-where upon the best practicable measures, let us see to it that all our movements are real advances and that we never trail our banner.

X.-Constitutional Amendments.

We call for the aid of State and National constitutional amendments for the suppression of the manufacture and sale of alcoholic beverages. Confident that a very considerable and respectable portion of American citizens desire to take their cause against the saloon for adjudication before the great tribunal of the sovereign people, whose prerogative it is, in a country like ours, to decide fundamental issues in the last resort, we believe it to be the wisest policy, and the supreme duty of all

No. 2200 . 


\section{Temperance and Prohibition.}

legislative bodies, to enact such legislation that, under the forms of the Constitution, the people may protect the home against the saloon, by no-license votes, under a local option regimen, and, as soon as possible, by constitutional prohibitory amendments.

XI.-Abolition of tile liquor Traffic in the District of Colunbia.

Inasmuch as we are credibly informed that bills are now before both houses of Congress for the abolition of the traffic in alcoholic beveragres in the District of Columbia, and inasmuch as the wisest statesmen and philan. thropists have often pronounced the liquor tratfic one of the direst enemies of civilization and human progress; and inasmuch as the Congress of the United States possesses unquestioned authority to abolish this traffic in the District of Columbia; therefore, this General Conference of the Methodist Episcopal Church, representing seven millions of communicants and adherents in these United States, respectfully memorialize Congress to No. 220 . 


\section{Temperaxce and Prombition. 11}

pass a bill which shall outlaw the liquor traffic in the District of Columbia; therefore,

Resolved, That a copy of this memorial shall be forwarded to Congress, signed by the Secretary of the Board of Bishops and the Secretary of the General Conference.

\section{XII.-Inter-State Liquor Traffic.}

Inasmuch as human experience has taught that the use of alcoholic beverages is a national curse, blighting the lives, corrupting the morals, and sapping the material strength of the commonwealth;

And inasmuch as certain States, namely, Maine, Kansas, Iowa, Vermont, and Rhode Island have enacted laws prohibiting the manufacture and sale of alcoholic liquors as beverages;

And inasmuch as said Supreme Court of the United States has decided that such legislation is constitutional;

And inasmuch as said Supreme Court has decided that intoxicating liquors, in original packages, may be carried or transported from No. 220 . 
other States, and from foreign countries, and delivered to consignees within the several States before named;

Therefore, it is the judgment of this General Conference of the Methodist Episcopal Church, that when the people of any State, by due legislative enactment, pronounce such articles contraband, on account of their injurious effects upon the people, it is then the duty of the General Government to declare said liquors liable to exclusion and confiscation.

We would also respectfully inquire whether the right, long claimed by Congress, to promote inter-State commerce, for the real or supposed good of the State, does not imply the right and duty also to restrict or prevent such inter-State commerce as inflicts real or supposed injury upon States, and especially when the States themselves have so adjudged and enacted by-laws prohibiting the manufacture and sale of alcoholic beverages?

In view of the foregoing reasons, this General Conference of the Methodist Episcopal Church, in quadrennial session assembled, No. 220 . 
respectfully and earnestly memorialize the Congress of the United States to adopt such legislation as will secure to States with prohibitory liquor laws the undisturbed benefits of the restrictive and prohibitory provisions enacted for their self-defense against a most noxious and destructive evil.

Resolved, That a copy of this memorial, signed by the Secretary of the Board of Bishops and the Secretary of the General Conference, be forwarded to Congress.

\section{XIII.-Rum and Native IHeathen.}

It is a matter of record that the advent among the heathen of men educated under the light of the Gospel is associated with the blackest curses that have blighted the lives of those for whom Christ died. While, in one pathetic sense, Ethiopia has stretched forth her hands unto God, in one other sense the "Dark Continent" may well stretch forth her hands in prayer for protection against those who have stained her shores with a trail of blood that reddens "the middle passage" 
between Africa and our inconsistent republic. Little wonder that the poor African shudders at the name of Christian America.

The history of the slave-trade is enough to make the "West Coast" verily hate the name of those who desolated her borders, and caused her ebony Rachels to mourn for the children who met a fate worse than death. Worse than night-attacks; worse than chains for innocent babes; worse than the prostitntion of mothers; worse than the wailing caravan; worse than the sweltering barracoon; worse than the stifling slave-ships; worse than the shameless auction block; worse than the fetter, the whip, and the separation of families; worse than the traftic in human muscles and souls is the inhuman trarle in Rem which now crowns the outrage to which the natives of Asia and Africa are subject at the hands of nominally Christian States!

No fetters that bind men in human slavery are comparable to the bondage to human appetite which makes the stricken victim an impotent consenting party to his own ruin No. 220 . 
and degradation. Under the sacred name of "Christian commerce" cargoes of rum are carried abroad to fasten upon those children of nature a blight that has no parallel in the list of curses which follow in the trail of civilization. You hear of whole tribes falling into the fate that has already ruined the North American Indian. We read of entire villages lying in the stupefaction of a simultaneous debauch. We hear the pathetic wail of native chiefs who curse the day that heralded the advent of the white man. We read of thousands of women and children victims of the poison brewed in American, English, and European distilleries.

Meantime, God is angry with the ruthless traffic that ruins the bodies of men and imprisons their souls in the bonds of "the second death." Among the cloud of witnesses who have protested against this wrong is Sir Richard Burton, the famous African traveler, who declares his sincere belief that-

"If the slave-trade were revived, with all its horrors, and Africa could get rid of the No. 220 . 
white man, with the gun-powder and rum which he has introduced, Africa would be the gainer in happiness by the exchange."

While we are combating this evil and its sway among those who, realizing its fruits, may be supposed to prefer and procure their own degradation, it is the duty of Christian nations to unite to protect those who, like children, would seem to be the wards of civilization; therefore,

Resolved, 1. That this General Conference declares its sincere sympathy with the efforts being made by our English brethren, by the National Temperance Society, in this city, and others, to abate the direful curse of rum, which desolates the doubly "Dark Continent."

2. That we will hail the day when both bond and free shall be manumitted from the thralldom of the drink-traffic, and when all men shall unite to anathematize him "who putteth the bottle to his neighbor's lips."

HEx' \& IATOX, Fith Ave, and Twentieth St., New York.

Caxsmot :- ETowe, Cinnunati.

№. 290. 